\title{
Preaching to the converted: Parliament and the Proscription Ritual
}

This article explores UK Parliamentary debate around the proscription - or banning - of terrorist organisations. It argues that these debates are usefully conceptualized as a form of political ritual organized around a core script, established participant roles, a shared respect for the performance of democracy, and a predictable outcome. Taking these ritualistic aspects seriously extends research on proscription by highlighting the importance of the procedures through which such organisations are produced as requiring exclusion from the UK's body politic. The article therefore makes three contributions. First, it provides a sustained empirical analysis of data from every relevant UK Parliamentary debate on proscription between 2001 and 2014. Second, it moves academic debate on proscription beyond questions of the power's effectiveness and legitimacy. And, third, it contributes to contemporary work on political ritual by offering a new heuristic for the analysis thereof centered on four dimensions: orchestration, constitutivity, sedimentation and performativity.

Keywords Ritual; Parliament; Performativity; Proscription; Counter-terrorism; British Politics

Recent years have witnessed a belated burgeoning of interest amongst political scientists in the ritualistic and ceremonial aspects of parliaments. For contributors to this research, it is vital that we take seriously Parliament's 'symbolic dimensions of political action' (Atkins and Finlayson, 2014, p.15) in order to 'trace the circulation of meanings, the particularity of institutional cultures and the sedimentation of power in political institutions' (Rai, 2010, p.284). Rituals in parliamentary settings have profound importance in the constitution of political realities within and beyond this rarified space, and attention to them is vital in order to understand the subtle workings of contemporary political power:

In parliaments, rules and norms become in/visible through ceremony and ritual - mirroring dominant social relations on the one hand and, on the other, almost through a sleight of hand, making them disappear from view (Rai, 2010, p.287)

This article contributes to this research by approaching UK Parliamentary debate on the proscription of terrorist organisations as a specific form of political ritual. The power of proscription, as demonstrated below, is a weighty one with consequences that include the outlawing of organisations from a designated territory, and the criminalization of support for, and membership of, banned groups. As of May 2016, sixty-six 'international terrorist organisations' are proscribed under the Terrorism Act 2000 in the UK, with a further fourteen organisations proscribed in Northern Ireland under previous legislation. ${ }^{\mathrm{i}}$

The article argues that proscription offers an excellent opportunity for exploring the workings and implications of parliamentary ritual for two reasons. First, the symbolic importance of this power is widely acknowledged by advocates and critics alike. As Hazel Blears argued in a 2005 debate, proscription 'sends out a strong signal ... that the UK rejects such organisations and their claims to legitimacy' (Blears 2005). Second, efforts to extend the UK's list of proscribed groups take place within discrete, selfcontained debates which are heavily orchestrated and marked - amongst other things - by a core script, established roles, a shared respect for the performance of democracy, and a predictable outcome. The bounded, formulaic nature of these renders this power a 
conceptually and methodologically promising case through which to explore the operation of contemporary political ritual.

The article begins with a brief introduction to proscription and its exercise, before reviewing existing research on this power. Here we point, first, to a surprising lack of engagement with proscription in general - especially beyond legal scholarship - and, second, to a concern with this power's symbolic significance. Although sympathetic to this latter insight, we argue that proscription's symbolism is more widely invoked than researched or theorized. Moreover, interest in this symbolism is far more frequently directed to the outcome than the debate of proscription decisions.

To address these limitations, and to highlight the importance of parliamentary debate around proscription decisions, a second section introduces sociological and anthropological research on the role of ritual in modern society. Drawing on this, and its political science interlocutors, we present a theoretical framework for the reading of political ritual organized around four dimensions: orchestration; constitutivity; sedimentation; and, performativity. A third section then applies this framework to an empirical study of every proscription debate between 2001 and 2014 in the UK Parliament: twenty-three debates in total. Approaching these debates as ritual, we argue, sheds light upon: the preclusion of dissent and inevitability of cross-party consensus therein; the preservation and reinforcement of Parliament's sovereign right to delineate the parameters of legitimate political enterprise; and, the importance of ritual for the constitution of political reality, including the production of newly-banned 'terrorist' organisations.

The article's contribution is, therefore, threefold. First, it offers a detailed empirical analysis of a significant body of original primary research material totalling approximately 148,500 words and stretching across three British governments. Second, it complements existing scholarship on proscription which is limited in scope and primarily oriented around questions of effectiveness and legitimacy. Our emphasis on the constitutive function of the proscription ritual here offers an alternative approach to the causal logics underpinning these questions ('how does proscription affect terrorist organisations or liberal democracy'), and provides a far more engaged theorisation of the power's symbolic dimensions. Third, it contributes to contemporary work on political and parliamentary ritual by developing a novel political ritual heuristic.

\section{Proscription and its precursors}

In the UK, Section 3 of the Terrorism Act 2000 empowers the Home Secretary to lay an order before Parliament for the designation and proscription of a terrorist organisation. The Home Secretary's order must acquire the assent of both Houses of Parliament before it takes effect. Parliament may only accept or reject a proscription order in its entirety, even if multiple organisations are included on an order, and no amendments are permitted. These powers empower the Home Secretary to determine, first, that an organisation is terrorist, insomuch as it:

commits or participates in acts of terrorism; prepares for terrorism; promotes or encourages terrorism (including the unlawful glorification of terrorism); or is otherwise concerned in terrorism. (Section 3(5) of the Terrorism Act 2000)

Second, - for organisations deemed to meet this determination - whether proscription is a 
proportionate course of action. To do so, the Home Secretary may consider the following:

the nature and scale of an organisation's activities; the specific threat that it poses to the UK; the specific threat that it poses to British nationals overseas; the extent of the organisation's presence in the UK; and the need to support other members of the international community in the global fight against terrorism. (Explanatory Memorandum to the Terrorism Act 2000).

Should organisations change their name to circumvent proscription, Section 3(6) of the Act allows the Home Secretary to make an order treating the new name as an alias for the group originally proscribed.

Proscription triggers a range of penalties for those subject to this power. For example, it becomes a criminal offence to: belong, or profess to belong, to a proscribed organisation; to support, or solicit support, financial or otherwise for the organisation; to support, organise, or speak at meetings promoting the organisation; or to wear or display symbols of support. Proscription also prompts a range of supplementary powers allowing, for example, agencies to deny entry to the UK, or to seize/freeze an organisation's assets and/or disrupt its online communications.

Importantly, proscription is not a modern conceit. The authority to banish an individual or group from a designated territory or political community is a longstanding feature of sovereign power. In ancient Roman law, the phrase vitae necisque potestas 'power of life and killing' - summarised this privilege (Westbrook, 1999). In pre-Magna Carta Britain it manifested as 'outlawry', in which the sovereign retained the power to designate his or her enemies as caput lupinum: 'may his be a wolf's head'. This metaphorical pronouncement carried considerable material weight, permitting (encouraging, in fact) any individual to kill said individual with impunity, as if culling a wolf (Richards, 1902, p.298).

\section{The symbolism and politics of proscription}

Despite proscription's significant consequences, scholarly scrutiny of this power remains surprisingly limited. Legal scholars have, to date, led the way in exploring proscription's ambitions, achievements and implications for liberal democracy, with comparatively little political science research on its symbolic and performative dimensions (though see de Goede, 2011), As Muller (2008, p.128; see also AUTHORS, 2014, 2015 \& 2016) indicates, these dimensions are long overdue for sustained analysis:

Proscription regimes are not simply legal tools against terror but ideological and political ones as well. They communicate societies' disfavour on the most profound scale.

Critics of proscription within the UK and beyond point to this power's deployment for goals beyond its ostensible purpose of countering terrorism. The US equivalent - the list of Foreign Terrorist Organisations - for instance, has been criticized for becoming 'increasingly politicized' and shaped by the prevailing political environment (Shapiro, 2007, p. 548), rather than threats to US security (Nadarajah \& Sriskandarajah, 2005, p. 96). As Shapiro (2007, p. 579) puts it: 'the only distinction between freedom fighters and terrorists may be the Executive Branch's predilection for that group or not'. Such concerns are also, at times, tied to the opposite outcome whereby - as Cameron (2003, p.237) argues of the EU's regime - 'there can be, cynical, political reasons for not wanting to blacklist [a group]', even if regarded as 'mainly terrorist'. Selectivity in 
proscription's deployment (Muller, 2008, pp. 128-129), therefore, has considerable power to shape the outcome of political struggles by depriving designated groups of recognition and support. On this view, proscription may impede peace processes (Gross, 2010; Haspeslagh, 2013; Hogg, 2008, p. 312; Sentas, 2010, p. 17) and, potentially, even shoreup oppressive regimes (Sentas, 2010, p. 16). What is more, the politicised deployment of proscription can thereby operate contrary to its own ends:

[T] here should be no illusion about how the infusion of politics into law by this process has degraded the legal integrity of a number of proscription regimes and actively hindered the ability of third parties and the international community to resolve certain conflicts through peaceful means (Muller, 2008, p. 128)

A second series of criticisms concern proscription's effects on citizenship and democracy. For some, the delegitimisation projected by proscription can have profound consequences for domestic, often minority, constituencies that might subsequently be seen as 'guilty by association' with newly proscribed groups: "anyone or any activities associated with [proscribed] organizations can now be criminalized. It is at this point that the [Terrorism] Act serves to create a "suspect community" (Pantazis \& Pemberton, 2009, p. 652; also Sentas, 2010, p. 16). This is illustrated in the Sri Lankan government's proscription of the LTTE which - for some - simply entrenched the state's long-standing hostility toward the Tamil community:

The deliberate conflation of 'terrorism' with the Tamil political project by successive Sri Lankan governments has produced a political culture in which the main (Sinhala) parties routinely vie to adopt more hard-line positions on the 'ethnic question' a practice which began as long ago as 1956. (Nadarajah \& Sriskandarajah, 2005, p. 98).

A related concern is the resentment and alienation proscription may cause within diaspora communities sympathetic to opposition groups proscribed in their host country (Pantazis $\&$ Pemberton, 2009; Sentas, 2010, p. 16). For Muller, 'The illegitimate or legally botched use of these proscription procedures is dangerous as it breeds long-term resentment among many exiled dissident groups and communities' (Muller, 2008, p. 129). His assessment of the banning of the Kurdistan Workers' Party (PKK) goes further still, arguing, 'If anything the manner by which the proscription regime was deployed merely fuelled the PKK's eventual return to violence as all avenues for dialogue were closed' (Muller, 2008, p. 128). On this view, proscription 'can undermine peace efforts, exacerbate violence and further entrench and broaden conflict' (Hocking, 2003; also Hogg, 2008, p. 312; Shapiro, 2007).

Finally, proscription stands also accused of serving symbolic ends, conjuring a seemingly-tangible foe for the state. Hogg, for example, views the formulation 'organization' as ill-fitting for the reality of contemporary terrorist campaigns, thus “invoking the word 'organisation' may therefore be mostly symbolic, to provide illusory comfort by imposing a familiar shape on a formless threat" (2008, p.303). On this view, proscription contrives the very existence of terrorist groups, fulfiling a 'denunciatory function' (e.g. Cameron, 2003, p. 237) and giving assurances that government, 'has sought, identified, and blacklisted...enemies abroad' (e.g. Shapiro, 2007, p. 579). In working thus, listing procedures are mechanisms which 'delegitimise those who use [terrorist] methods' (Cameron, 2003, p. 237) and, thereby, their 'attendant struggles' 
(Muller, 2008, p. 128). Significantly, the act of proscription in Parliament is one which occurs at the behest of the executive (AUTHORS, 2014).

Two implications follow from this brief overview of relevant literature. First, research on proscription is limited in several ways: it is comparatively sparse, and dominated by legal scholarship; it is overwhelmingly concerned with this power's effectiveness and normative implications; and, although proscription's symbolic power does attract regular attention, this is far more frequently directed to proscription decisions than debate. Second, inattention to the proscription process means that proscription's ability to shed light upon latent state power is often overlooked, especially as this process proceeds through representative institutions, yet is extremely rarely resisted or questioned by legislatures (AUTHORS 2014).

These limitations are a little surprising given the extent of scholarship on the construction and implementation of counter-terrorism powers more broadly. Scholars associated with 'critical terrorism studies', for instance, have written widely on the performative and discursive movements through which counter-terrorism powers are framed and 'sold' to various audiences (e.g. Jackson 2005; Jarvis 2009; Oren \& Solomon, 2o015). There is also considerable theoretical and empirical literature on exceptionalism, the dominance of executive power, and the absence of political scrutiny in this broader counter-terrorism context (e.g. Donohue 2008; Neal 2012), wherein the 'issue of security [often] compounds the unequal power relations of the parliamentary field' (Neal, 2012, p.364). To build on this wider research into counter-terrorism law-making, and to begin to address the above limitations within proscription scholarship, we turn now to a largely unconnected literature on (political) ritual.

\section{Politics and ritual}

Debate on the socio-political significance of ritual has been as varied as long-standing, since Émile Durkheim established the contours for sociological analysis of religious rituals as mechanisms of social integration (Durkheim, 2001). His work framed rituals as the epicentre of social order: a means to organize sacred symbols and beliefs, reinforce group norms, and cohere social solidarity (2010, pp.355-365). Subsequent scholarship largely, but not exclusively, in anthropology and sociology - has diverged radically on the social significance of ritual; whether rituals operate, as Rappaport suggests, as the fundamental means of constructing human cognition; or to achieve social solidarity and resolve conflict (Gluckman, 1962; also Bell, 2011, p.172); as a mechanism for controlling violence (Girard, 1977); or for the transmission of culture and identity (Turner, 1967). For others still, rituals might be thought of as 'purely activity' with 'no meaning, goal or aim' (Staal, 1996, p.131).

The role of ritual in political space is our primary concern here, and the extent to which standardized and repetitive symbolic practices might, 'serve certain political interests and undermine others' (Kertzer, 1989, p.87). This concern is represented in a nascent but important scholarship on British politics (e.g. Atkins and Finlayson 2014; Crewe 2005; Lovenduski, 2012; Rai, 2014; Rhodes, 2005; Waylen, 2010); securitization (Oren \& Solomon, 2015) and public policy (t'Hart, 1993). Despite differences therein, for many of these authors rhetorical and performative analysis can be employed to reveal the 'symbolic, ritualised aspect of contemporary political and ideological practices' of Parliament (Atkins and Finlayson, 2014). Analyzing Lords debates, for example, Emma 
Crewe posits a 'theatrical quality' to the 'rituals of debate' that are laden with 'rules and symbols of engagement' (2005, p.184). Recognition of these aspects of Parliament, for Rai, is crucial, for our understanding of representative institutions is incomplete without consideration of the 'institution-specific culture which socializes members in their participation’ (Rai, 2010, p.281).

This scholarship matters because it develops earlier observations of the influence of subtle, symbolic and ritualised political behaviours evident in influential works on power. Bachrach and Baratz, for instance, suggest that in reinforcing social and political values, power works via an institutional 'mobilization of bias', understood as 'a set of predominant values, beliefs, rituals, and institutional procedures ('rules of the game') that operate systematically and consistently to the benefit of certain persons and groups at the expense of others' (our emphasis, 1970, p.43). Developing this, Steven Lukes regards analysis of rituals' 'cognitive role' in society as of fundamental importance, since they give meaning to social relations and organize perceptions of past, present and future:

[ritual] helps define as authoritative certain ways of seeing society: it serves to specify what in society is of special significance, it draws people's attention to certain forms of relationships and activity - and at the same time, therefore, it deflects their attention from other forms, since every way of seeing it also a way of not seeing.' (Lukes, 1975, p.301)

Lukes presents rituals as 'rule-governed' symbolic activities that focus participants' attention to 'objects of thought and feeling' held to have special significance (1975, p.291). Rule-governed, for Lukes, describes patterned and normative pressure on participants (1975, p.290) which operate as 'modes of exercising, or seeking to exercise, power along the cognitive dimension'. More recently, Lovenduski (2012) develops Lukes' perspective of ritual to portray the gendered dimensions of Prime Minister's Questions in the House of Commons:

Rituals are a means of control, part of the mechanisms that may privilege certain kinds of masculinity, thereby sending a strong symbolic message to women that politicians are men who have repertoires of behaviour that are not available to women (and some men) (2012, p.317).

Waylen, similarly, draws on Lukes to locate ritual within institutionalist literature, emphasising the working of rules and norms in formal and informal institutions. Here she frames ritual as key to understanding 'change, power and conflict' and actors' behaviours in 'legislatures as institutions' (2010, p.353). Yet one of the most prominent scholars on ritual, Shirin M. Rai, critiques Lukes' characterisation. She claims that while Lukes reveals the 'cognitive dimension' of ritual in political contexts, he fails to account for the 'sedimented and reflective power of political ritual - of how power is reflected as well as challenged in and through political ritual' (2010, p.290). Rituals, for Rai, are a means by which government power is 'constructed and reproduced', and 'new meanings of power are inscribed' (2010, p.287). Thus, although this scholarship shares an emphasis on the importance of ritual for political power, there is, clearly, disagreement over how this materializes. As will become clearer in the following section, our emphasis in this article is on the first of the four perspectives delineated in Bell's typology: (i) how rituals empower those in charge of rituals; (ii) how that power is also constrained; (iii) how rituals come to dominate participants; and (iv) how that domination involves 'negotiated participation', which in turn may empower participants (Bell, 2011, p.211). 


\title{
Understanding ritual
}

Although the above demonstrates the continuing contestation over the significance of ritual, it it possible to identify core characteristics thereof as useful points toward a heuristic (see Grimes 2014 and Rappaport 1999). Consider the following definitions:

\begin{abstract}
Ritual action has a formal quality to it. It follows highly standardized, structured sequences and is often enacted at certain places and times that are themselves endowed with a special meaning. Ritual action is repetitive and, therefore, often redundant, but these very factors serve as an important means of channeling emotion, guiding cognition, and organizing social groups (Kertzer, 1989, p.9).
\end{abstract}

[Ritual includes] 'performance, formality, invariance, inclusion of both acts and utterances, encoding by other than the performers' (Rappaport, 1999, p.24).

[Rituals] may use a delineated and structured space...; a special periodicity...; restricted codes of communication to heighten the formality of movement and speech; distinct and specialized personnel; objects, texts, and dress designated for use in these activities alone; verbal and gestural combinations that evoke or purport to be the ways things have always been done; ... particular physical or mental states; and the involvement of a particular constituency not necessarily assembled for any other activities (Bell, 2011, pp.204-5).

Kertzer, Rappaport and Bell together highlight several key characteristics that take us toward an understanding of ritual features, including: formality, specific sequencing, designated sites, social groups, historical repetition and cognitive guidance. Framed thus, everyday examples of ritual are not hard to identify and include, ${ }^{\mathrm{ii}}$ inter alia, those that are public - for example, the solemnity of commemorative wreath-laying at the Cenotaph and the poppy's ubiquity; those that are institutional - such as the annual Queen's Speech and the dragging of the newly-elected Speaker of the House of Commons to the Chair; the sectarian - for example, traditional parades in Northern Ireland; the secular - such asuniversity graduations; the religious - bar mitzvahs, confessionals, fasting, and so on; and the private - spreading of a deceased's ashes or drinking toasts. Further, the above three depictions underlines that, despite divergent views on ritual's role and significance ritual, there is scope for agreement on the identification thereof.

To develop this, the following offers a new heuristic for the study of political ritual. This heurestic emerges from our analysis of the particular proscription ritual in question, and is intended to shed light on the unfolding of political rituals, and their significance for generating particular outcomes (including through the preclusion of dissent). It is organized around four prominent qualities, that are simultaneous and interactive, but neither fixed nor determined: (i) orchestration: rituals as assemblages of symbolic behaviours; (ii) constitutivity: rituals as a means of producing reality; (iii) sedimentation: rituals as the reinforcement of constructed realities via repetition; and (iv) performativity: rituals as a means to produce new ways of seeing the world. These attributes guide our understanding of the broad contours of a phenomenon found across histories, cultures and traditionsiii. They are derived from the above work, though the assemblage is our own.

At their base, rituals are an orchestration of specific behaviours that are laden with symbolisms. They typically occur within specific contexts - a time, a place - and proceed via a pre-configured template of actors (in roles), narratives and incantations 
toward a predicted outcome (Kertzer; pp.9-12; see also Bell, 2011, pp.204-5; Rappaport, 1999, p.24).

Second, rituals are ontologically constitutive: they forge an interpretation of the world. Kertzer argues; 'Through ritual, beliefs about the universe come to be acquired, reinforced and eventually changed' (p.9). The interplay of beliefs and symbols is central to rituals' constitutive function in which (a version of) reality - as an artifice of values, beliefs, norms - plays out through carefully selected narratives. The form taken by any particular ritual is therefore, "partly attributable to its morphological characteristics. Its medium is part of its message' (Emphasis added, Moore \& Myerhoff, 1977, p.8).

Third, rituals sediment their constituted realities. Through their 'invariance' (Rappaport, 1999, p.24) or 'repeated and simplified cultural communication', observers and participants 'share a mutual belief in the descriptive and prescriptive validity of the communication's symbolic contents' (Alexander, 2006, p.29). In their reiteration over time, rituals reinforce and solidify incumbent symbols and ontologies. Rituals maintain links with the past by remaining internally consistent and 'only infrequently depart from the expectations of actors and scripts (Alexander, 2006, p.41). Their 'sequestered' (Turner, 1977, p. 183) and 'homeostatic' (Goody, 1986, p. 21) character thereby serves to reinforce constituent symbols beliefs and values. Further, 'the repetitive uttering of these phrases is a condition of their performativity’ (Oren \& Solomon, 2015, p.320)

Thus, finally, we draw attention to the performative dimension of ritual. Following Alexander's claim that 'all ritual has at its core a performative act' (2006, p.38; see also Rappaport, 1999), we emphasise the combination of perlocutionary and illocutionary efforts in ritual that together 'produce ontological effects, that is, that work to bring into being certain kinds of realities' (Butler, 2010, p.147; see also Oren \& Solomon, 2015, pp.320-4). In this sense, performativity is effectual, insofar as it supplies 'an alternative to causal frameworks for thinking about effects' (2010, p.148) and is intrinsic to ritual's repitition in doing so can 'counter a certain metaphysical presumption about culturally constructed categories' (2010, p.148).

Operationalising this heuristic reflects our key research interests as political scientists, and returns us to the significance of ritual bracketed above. Ultimately, we are concerned with the means by which legislatures construct specific threats (here, terrorist groups) to the identity and values of an equally constructed national self. In this, the article seeks to extend the claims of scholars who emphasise how rituals can achieve political interests (i.e. Kertzer, 1989; Lukes, 1975). Political rituals, as understood by Oren \& Solomon, play an ontological role in constructing security realities through 'the simultaneous interweaving of linguistic repetitions with speakers' and audiences' material performance' (2015, p.316). On our analysis here, the act of proscription ontologically 'creates' an organisation - ascribing it 'terrorist' qualities; transmits particular (versions of) reality - i.e. that such organisations groups represent a threat to 'our' values and beliefs; and does so while reinforcing particular value-systems - i.e. it is Parliament's sovereign right to thus make that organization's existance criminal. Such reality-making is powerful, and achieves its purchase by shaping cognition of those involved in, or addressed by, rituals. Thus we concur with the view of Gusfield \& Michalowicz that 'the values and norms of ritual actions may be so axiomatic as to preclude the actor from seeing it in relation to either part or all of society' (1984, p.421). 
Table 1 summarises our heuristic, with examples taken from the ritual of proscription to which we now turn.

INSERT TABLE 1 AROUND HERE: Table 1. Analysing political ritual: a framework with example

\section{The proscription ritual}

To illustrate the above framework's value, we turn now to the ritualistic aspects of Parliamentary debate on proscription. To do this, we draw on material from each of the relevant twenty-seven debates within the UK's Houses of Parliament between October 2002 and June 2014. These self-contained debates on this statutory instrument represent every attempted - and ultimately every successful - addition to the list of proscribed organisations within the UK since the passage of the Terrorism Act 2000 which instituted the current proscription regime, as well as a House of Lords Amendment Order on the deproscription of the People's Mujaheddin Organisation of Iran (PMOI). The full record of debates includes only orders (statutory instruments) subject to the affirmative procedure. Amendments to a banning order to keep track of organisations that change their name are subject to the negative procedure, which do not require debate in Parliament and are approved after a period of time, unless resisted by Parliament, which has never happened.

The transcripts from each of the twenty-seven debates were accessed online via Hansard and constitute a corpus of approximately 148,500 words. Following collection of our data, each debate was subject to a detailed immersive reading using the 'framework' approach (Ritchie and Spencer, 2002). This involves a systematic process of sifting, charting and sorting research material for the purposes of summarising and classifying large volumes of data in a manner grounded in the text's own categories. Below we explore how proscription debates accord with the four core dimensions of ritual set out above.

\section{The Orchestration of the Proscription Ritual}

\section{a. Fixed authority, place, time and actors}

As with all legislation, proscription occurs in Parliament's specific, pre-defined time and place to which a particular cast of actors alone have physical access, though it is 'performed' to wider audiences via television and other media, and, after the fact, Hansard. The process, as outlined above, is only initiated at the fiat of the Home Secretary. Her order is laid before Parliament in accordance with stipulated protocols, and introduced to the House by the Under-Secretary of State for the Home Department, or a deputy. Once the order is put to the House, participation in these debates occurs only via highly stylized language adhering to prefigured types of speech set out in procedural rules, for example:

A parliamentary question must:

- either (a) seek information ('what, how many, when...') or (b) press for action ('if he will...'); 
- not offer or seek expressions of opinion;

- not convey information nor advance a proposition, an argument or debate (House of Commons Information Office, 2010, p.3)

Further, the format of the process conforms to a structured inter-personal interaction scheduled and policed by key actors - the Speaker of the House (assisted by the House's Table Office clerks) - who may determine the Order of Business, the posing of supplementary questions, the length of time for any response, and so on. This authority ensures the ritual adheres to an entrenched structure implicitly understood by all participants, and strengthened by frontbench agreement between the main parties. ${ }^{\text {iv }}$ Unlike other debates, no divisions have ever been called in the case of proscription: when a motion is put, it is agreed.

\section{b. A core script}

Proscription debates forego the turbulence and diversity of many non-security debates. Though individual participants change, e.g. swapping opposition for government, this ritual's core incantation remains more or less consistent (variations underlined):

I beg to move,

That the draft Terrorism Act 2000 (Proscribed Organisations) (Amendment) Order 2012, which was laid before this House on 2 July, be approved.

The Government are determined to do all we can to minimise the threat from terrorism to the UK and our interests abroad. Proscription of terrorist organisations is an important part of the Government's strategy to tackle terrorist activities. We would therefore like to add the organisation Indian Mujahideen - the IM-to the list of $\underline{47}$ international terrorist organisations, amending schedule 2 to the Terrorism Act 2000. This is the 10th proscription under the 2000 Act.

Section 3 of the 2000 Act provides a power for the Home Secretary to proscribe an organisation if she believes it is currently concerned in terrorism. The Act specifies that an organisation is concerned in terrorism if it commits or participates in acts of terrorism; prepares for terrorism; promotes or encourages terrorism, including through the unlawful glorification of terrorism; or is otherwise concerned in terrorism. The Home Secretary may proscribe an organisation only if she believes it is concerned in terrorism. If the test is met, she may then exercise her discretion to proscribe the organisation. (Parliamentary Under-Secretary of State for the Home Department, James Brokenshire: HC Debates col.1020, $4^{\text {th }}$ July 2012)

As outlined below, this scripted opening is followed by familiar lines of discussion and questioning. These include: explicit proclamations of respect for the ritual; assurance of bipartisan support; consensus on what proscription is and does; consensus on proscription's necessity, and alignment with liberal values; repetition and reaffirmation of the objects of proscription. These themes, in recurrence, form this ritual's scripted elements, viz. those narratives that are both expected and permitted.

\section{c. Respect for the ritual}

The sanctity of proscription is underlined by frequent expressions of the seriousness of this debate, and by the admonishing of MPs transgressing, often unspoken, rules of propriety. Debate on proscription is replete, for instance, with reference to its 'importance' and the 'serious' decision at hand. Framed as 'a heavy power' (Filkin 
2002), 'an important power' (Blears 2005b) and a 'very serious matter' (McNulty 2006), Parliamentarians repeatedly emphasise their understanding of the task's importance. We also see criticism of parliamentary practice deemed short of such standards, whether via the chastising of absent colleagues - 'In previous debates of this kind, the House has been almost empty' (Vaz 2011) - or through reproach for flippancy: 'these are very serious issues and it is not appropriate to have shouty debates across the Dispatch Box on them' (Smith 2012). For Damian Green, Minister for Immigration at the time of a 2011 debate on Tehrik-e Taliban Pakistan (TTP), for instance: 'I regret that Opposition Front Benchers regard the matter as humorous...There are clearly serious issues about how this country attacks terrorism and defends itself against terrorists, so it is not the time for Opposition Front Benchers to regard something as amusing' (Green 2011).

\section{d. A predetermined outcome}

Offering explicit support to the Executive's order is a further common feature of proscription debate. Regardless of which party is in power, the Opposition preclude the failure of an order by providing a priori support - i.e. "I reassure the Minister that the official Opposition will support the order" (Grieve, 2005) - with dissent limited, typically, to objections of magnitude, "I am therefore pleased to support the orders, but we must go much further" (Gapes, 2014) or procedural propriety: "I support what the Minister is doing today, but I just want to be clear about the process" (Vaz, 2014).

This bipartisan consensus occurs under the auspices of national security cooperation: "There is a long tradition of cross-party co-operation on issues of national security, and the Opposition will support the Government's motion" (Johnson, 2013). Further, it is offered in spite of a (frequently acknowledged) shortfall in sharing the basis for the proscription order:

The Opposition do not have access to the same intelligence as the Home Secretary and the Minister. However, on the basis of the assurances that the Minister has given the House and the information that he has set out clearly today, the Opposition are happy to give the motion our full support (Johnson, 2014a).

Parliament's deference to the Home Secretary or her replacement reflects an a priori and explicit suspension of the Opposition's nominal function (to oppose). This leads to the counter-intuitive claim that 'seriousness' is the basis for relinquishing opposition and becoming complicit in the decision, even while acknowledging the imbalance of power:

Any proscription order should therefore be taken very seriously. For that reason, successive Governments have attempted to ensure that there is cross-party parliamentary support for proscription orders (Johnson, 2014b).

\section{Constitutivity}

\section{a. Intersubjective consensus on what proscription is/does}

Alongside recognition of the gravity of proscription decisions run reflections, in these debates, on the measure's efficacy for counter-terrorism. Portrayed, often, as a necessary though insufficient instrument - 'proscription is a useful power, but it will certainly not resolve the [terrorist] situation overnight' (Blears 2005c) - proscription is consistently positioned as a significant weapon in the Home Secretary's arsenal: 'there is not much 
doubt that it [proscription] has great value in disrupting the activities of terrorist organisations' (Bassam 2005b).

Part of this worth is its speediness of deployment: 'We have sought a shortened timetable to ensure that the power is as effective as possible' (Basam 2005c) with proscription orders here 'clinical and immediate' (Vaz 2014b). Also important, however, is the latitude afforded to well-positioned decision-makers: 'The Home Secretary may proscribe an organisation only if she believes it is concerned in terrorism. If that test is met, she may then exercise her discretion to proscribe the organisation' (McNulty 2008).

\section{b. Consensus on proscription's necessity, and alignment with liberal values}

Further consensus is evident around the lawful and normative probity of the proscription process. As the Minister for Policing, Crime and Counter-Terrorism put it in a debate on al-Shabaab: 'The decision to proscribe an organisation is not taken lightly. It entails building a case that meets the legal test under the 2000 Act, and which is examined by officials in the Home Office and other Government Departments. That case is assembled over many weeks and months' (Hanson 2010; See also Johnson, 2012).

Lest critics fear the scope for error or abuse opened by this combination of alacrity and discretion, proscription is also widely presented as impartial - 'We take action irrespective of the creed or nationality of those involved' (Blunkett 2002); evidence-based - 'this approach is the result of very careful intelligence gleaned from international sources' (Bridgeman 2002); rigorous - 'Decisions to proscribe are taken with great care by the Home Secretary, and it is right that the case for proscribing organisations must be approved by both Houses' (Brokenshire 2013); transparent - 'the criteria are clear, as are the offences that follow on from them' (McNulty 2008b); and open to appeal - 'if groups feel that they have been wrongly proscribed they have recourse to a review' (Blears 2005d).

At the same time, discussed further below, there is mention, even by proscription's advocates, of this power's limitations, which include procedural complications - 'I do not know or understand the procedure that puts the organisations together in one order' (McNulty 2007); possible (geo)political influences upon its deployment - 'there are tactical considerations as well, regarding the optimum time to intervene. We also need to work in collaboration with our international partners; there may be a reason why they do not want us to take action at a particular point' (Attlee 2013); and potential political trade-offs - 'failure to proscribe an organisation that turns out to be violent and to have terrorist intent could threaten British citizens on our soil, but equally, proscribing an organisation mistakenly or inappropriately could tie up significant resources' (Ruffley 2008). As McNulty (2008c) summarises: 'A proscription order is not a magic wand that makes things any easier'.

\section{Sedimentation}

a. Repetition and reaffirmation of the objects of proscription

Parliamentary debate on the extension of proscription powers follow, almost without exception, the same scene-setting. The order is introduced by the Minister, who offers a brief description of the power, the criteria for its usage, and consequences for newlydesignated groups. This description is typically then replicated near verbatim in the House of Lords, with reference in both Houses often made to previous uses of the power 
for additional context. Thus, in the first effort to add organisations to the list in October 2002, for instance, Home Secretary David Blunkett offered the following:

The proscribed organisations fall within criteria of which it will be useful to remind hon. Members. They are specified in the definition of terrorism provided in the Terrorism Act 2000, which refers to those who commit or participate in acts of terrorism, prepare for terrorism, promote or encourage it or are otherwise concerned with it. The factors spelt out alongside the original decision a year last February were as follows: consideration by the Home Secretary of the nature and scale of the organisations; the specific threat to the UK or British nationals overseas; and the presence and support of the international community. It is the support of the international community and the threat to our citizens overseas that we have weighed very carefully indeed, along with other factors, in proscribing the four groups (Blunkett 2002b).

In June 2014, the Conservative MP James Brokenshire, Minister for Security and Immigration, offered a similar account on the Coalition government's case for proscribing five additional groups including the Islamic State in Iraq and the Levant (ISIL). The one significant difference from Blunkett's of twelve years prior is the addition of the 'glorification of terrorism' offence from the Terrorism Act 2006:

Proscribing the groups that we are discussing today will send a strong signal to terrorists operating on both sides of the conflict in Syria and those who may be thinking of joining them. Under section 3 of the Terrorism Act 2000, the Home Secretary has the power to proscribe an organisation if she believes that it is currently concerned in terrorism. Under the 2000 Act, an organisation is concerned in terrorism if it commits or participates in acts of terrorism, prepares for terrorism, promotes or encourages terrorism - including the unlawful glorification of terrorismor is otherwise concerned in terrorism. If the test is met, the Home Secretary may exercise her discretion to proscribe the organisation (Brokenshire 2014).

This incantation which affirms the Home Secretary's competence to make a proscription order characterizes the beginning of proscription debates. The debate then proceeds toward a closing consensus which is little more than a facsimile of the opening statement, affirming that the pretext of the proscription has been unaffected by the intervening debate.

\section{Performativity}

As suggested by the above, the proscription ritual not only hosts the performance of democracy and scrutiny, it constitutes or calls into being proscribed organisations that are made concrete at the moment of their banning. This is the illocutionary power of proscription. The attempt to extirpate an organisation involves its creation and permanence in law: paradoxically, its continuing existence is cemented by the very power that seeks to vanquish it. The proscription ritual also, however, hosts perlocutionary claims to construct - or signal - the UK as a willing partner in the fight against terrorism and a hostile environment for the organisations it condemns. Yet these material and ideational components are not easily extricated. As Jarvis and Lister (2015) suggest, the purposes of counter-terrorism mechanisms are both ambiguous and multiple, serving symbolic, strategic and political functions.

Parliamentary debates on proscription illustrate this ambiguity well, with multiple functions claimed for this power. In a 2002 House of Lords debate, for instance, Lord Filkin argued that proscription both prevents and signals the immorality of terrorism: 
The impact of proscription is to make it more difficult for international terrorist organisations to operate in the United Kingdom and seeks to deter them from coming here in the first place ... [It] is a powerful signal of the government's and society's rejection of those organisations' claims to legitimacy (Filkin 2002b).

The presentation of these diverse functions has become more stylised in contemporary debate, with the following from Lord West of Spithead in a debate on Hezbollah:

The proscription of Hezbollah's military wing will contribute to making the United Kingdom a hostile environment for terrorists and their supporters. It will signal our condemnation of the support that Hezbollah provides to those who attack British and other coalition forces in Iraq, as well as Iraqi civilians. It will support our international partners in disrupting terrorist activity in the occupied Palestinian territories, and it will also send a strong message that the United Kingdom is not willing to tolerate terrorism either here or anywhere else in the world (West 2008).

Proscription, then, reduces the likelihood of planned terrorist attacks - 'proscription can be an important mechanism to disrupt activity' (Brokenshire 2013b), and complicates the preconditions required for terrorism - 'proscribing such organisations in the UK is a practical step to stop funding that supports them in other countries' (Mahmod 2007).

The ritual's perlocutionary dimensions are too manifest, with proscription explicitly acknowledged as a mechanism that seeks to shape the landscape of political enterprise - 'it also deters international terrorist organisations from coming to this country in the first place' (Blears 2005e); and has significant, and multiple, communicative roles from taking 'the drastic step of telling those who belong to, work for, and associate themselves with certain organisations that such activities are unacceptable in this country' (Hughes 2002), through to sending out 'a clear message that the United Kingdom takes seriously its role in fighting terrorism' (Scotland 2006). Proscription's ability to do all this as 'a vital part of our national security powers' (Johnson 2014b; see also Brown 2016) is augmented, in these debates, by reference to international cooperation - 'it provides a coherent approach involving the UN and other international partners in seeking to attack and undermine terrorism' (Blunkett 2002b); political consensus, being 'part of the mutuality and solidarity that we have expressed in the House on a number of occasions' (Blunkett 2002b); and popular domestic support - 'I believe - if I reflect on these matters carefully, as I have done - that the UK Somali community will welcome this action because it shows that we are concerned to tackle terrorism in their home country and the impact of such terrorism on the interests of citizens in their adopted country' (Hanson 2010b).

As the above demonstrates, thinking through proscription debates as a form of political ritual sheds considerable light on aspects of its operation and functions largely missed in existing work on this power. Specifically, reading these debates through the heuristic introduced in Table 1 demonstrates that whilst this particular ritual has its own specific characteristics - including its core incantation, consensus on its purposes, and the absence of division - it also evidences qualities that are common or even general to other political rituals. The former include its working toward a predetermined outcome which 
accompanies many, though not all rituals. The latter include respect for particular rules, and the performative function of ritual in (here) signalling terrorism's unacceptability. ${ }^{\mathrm{v}}$

\section{Conclusion}

The above analysis illustrates how an emphasis on the ritualistic qualities of proscription debate highlights its constitutive functions, predictable outcomes and repetitiveness. This lens, we suggest, brings into focus the symbolic and political strata of proscription, situating debate on this power within Parliament's broader matrix of structures, symbolisms, traditions, norms, hierarchies, procedures, patronages and roles:

The ritual legitimizes the power and institutionalizes it, but at the same time, the role of power holder itself becomes transferable, no longer the property of any particular individual (Kertzer, 1988, p.51).

As we have shown, the contours of proscription debates are highly scripted, conforming to a predetermined structure with little variation in their introduction, core narratives, or conclusions. Here we find a process in which identifiable (yet changing) actors are authorised inhabit specific roles and employ a script that varies little across time or government. This ritual: reaffirms 'our' (liberal, democratic) values, and their distance from the 'terrorist' other and involves the repeated lauding of the Parliamentary process at the same time as it militates against deviation and dissent. This is a ritual, moreover and most important of all - where the predicted outcome is, invariably, achieved. As Edelman noted, some time ago, 'policymaking procedures whose outcomes are known in advance amount to ritual and not to decisionmaking' (1971, p.22).

This ritual of proscription amounts to a performance of democracy in which the probity of process, the lawfulness of decision-making, and the process' alignment with democratic values are regularly affirmed. And, these incantations of democratic values, in turn, cement the legitimacy and licence of Parliament to retain the sovereign power to proscribe. In this sense, invoking democratic legitimacy is all the more necessary for Parliamentarians in their construction of newly-proscribed terrorist organisations. Whether equivalent powers in other countries evidence similar ritualistic qualities is an important comparative question beyond this article's scope. Indeed, much future work should be done on the varying rituals of counter-terrorism and security politics more generally, within and beyond the rarified space upon which we have here focused. Such work might, amongst other things: incorporate alternative methodologies such as elite interviews with current or former participants in these rituals; pay greater attention to the role of endogeneous factors including in relation to political party, parliamentary house, gender, or timing; consider parallels between this specific ritual and related debates on national security and beyond. Our aim here, however, has been to contribute to contemporary literature on proscription by pushing debate beyond questions of effectiveness, ethics and outcomes through original analysis into a significant body of primary research material. In so doing, we hope also to have contributed to literature on ritual by offering and illustrating a new heuristic framework for the study thereof derived from a detailed empirical analysis of a considerable, and largely un-researched, corpus of data. 


\section{References to Parliament Debates}

Atlee (2013) 11 July 2013: Column 494

Bassam: Hansard HL, 13 Oct 2005: Column 490

- (2005b) Hansard HL, 13 Oct 2005: Column 493

- (2005c) Hansard HL, 13 Oct 2005: Column 491

Blears, H. (2005a) Hansard HC. 13 Oct 2005: Column 467

- (2005b) Hansard HC, 13 Oct 2005: Column 466

- (2005c) Hansard HC, 13 Oct 2005: Column 484

- (2005d) Hansard HC, 13 Oct 2005: Column 469

- $\quad$ (2005e) Hansard HC, 13 Oct 2005: Column 467

Blunkett, D (2002) Hansard HC, 30 Oct 2002: Column 879

- (2002b) Hansard HC, 30 Oct 2002: Column 878

- (2002c) Hansard HC, 30 Oct 2002: Column 878

Bridgement Hansard HL, October 2002: Column 254

Brokenshire, J (2012) Hansard HC, $4^{\mid}$July 2012: Column 1020

- (2013a) Hansard HC, 10 Dec 2013: Column 203

- (2013b) Hansard HC, 10 July 2013: Column 455

- (2014) Hansard HC, 19 Jun 2014: Column 1281

Brown, L Hansard HC, HC 15 Mar 2016: Column 912

Filkin: (2002) Hansard HL, 30 October 2002: Column 252

- (2002b) Hansard HL, 30 October 2002: Column 252

Green, D. (2011): Hansard HC, 19 Jan 2011: Column 966

Grieve, D (2005): Hansard HC, 13 Oct 2005: Column 473

Gapes, M (2014): Hansard HC, 19 Jun 2014: Column 1293

Hanson (2010) Hansard HC, 4 Mar 2010: Column 1049

- (2010b) Hansard HC, 4 Mar 2010: Column 1050

Hughes: Hansard HC, HC 30 Oct 2002: Column 883

Johnson 4 July 2012 : Column 1022

- $\quad$ (2013 Hansard HC, 10 Dec 2013: Column 204

- $\quad$ (2014a) Hansard HC, 19 Jun 2014: Column 1287

- (2014b) Hansard HC, 19 Jun 2014: Column 1286

McNulty, T: (2006) Hansard HC, 20 July 2006: Column 491

- (2007) Hansard HC, 10 July 2007: Column 1369

- (2008) Hansard HC, 15 July 2008: Column 193

- (2008b) Hansard HC, 15 July 2008: Column 194

- (2008c) Hansard HC, 15 July 2008: Column 210

Mahmood, S (2011 Hansard HC, 19 Jan 2011: Column 969

- (2007) Hansard HC, 10 July 2007: Column 1371

Ruffley, D (2008) Hansard HC, 15 July 2008: Column 197

Scotland HL: 24 July 2006: Column 1611

Smith (2012): Hansard HL, 5 July 2012: Column 895

Vaz, K (2011a) Hansard HC, 19 Jan 2011: Column 970

- (2014) Hansard HC, 2 Apr 2014: Column 949

- (2014b) Hansard HC, 19 Jun 2014: Column 1290

West (2008) Hansard HL, 17 July 2008: Column 1348 


\section{References}

AUTHORS: 2104, 2015, 2016

Alexander, JC (2006)

Atkins, J and Finlayson, A (2014) 'As Shakespeare so memorably said...': Quotation, rhetoric, and the performance of politics, Political Studies, 1-18.

Bachrach, P and Baratz, MS (1970) Power and poverty: Theory and practice. Oxford: Oxford University Press.

Bell, C (2011) Ritual theory, ritual practice. Oxford: Oxford University Press.

Butler, J (2010) Performative agency, Journal of Cultural Economy, 3(2), 147-61.

Butler, J (2013) Excitable speech. Abingdon: Routledge.

Cameron, I (2003) European union anti-terrorist blacklisting, Human Rights Law Review, $3,225$.

Crewe, E (2005) Lords of Parliament: Manners, rituals and politics. Manchester: Manchester University Press.

de Goede, M (2011) Blacklisting and the ban: Contesting targeted sanctions in Europe, Security Dialogue, 42(6), 499-515.

Donohue, LK (2008) The cost of counter-terrorism: Power, politics and liberty. Cambridge: Cambridge University Press.

Durkheim, E (2001) The elementary forms of religious life. Oxford: Oxford University Press.

Girard, R. (1977). Violence and the Sacred. 1972. Trans. Patrick Gregory. Baltimore: Johns Hopkins UP.

Gluckman, M. and C. D. Forde (1962). Essays on the ritual of social relations, Manchester University Press.

Goody, J (1986) The logic of writing and the organization of society. Cambridge: Cambridge University Press.

Grimes, R. L. (2013). The craft of ritual studies, Oxford University Press.

Gross, J (2011) Proscription problems: The practical implications of terrorist lists on diplomacy and peacebuilding in Nepal, Praxis, 26, 38-59.

Gusfield, JR and Michalowicz, J (1984) Secular symbolism: Studies of ritual, ceremony, and the symbolic order in modern life, Annual Review of Sociology, 10, 417-35.

Hart, P t' (1993) Symbols, rituals and power: The lost dimensions of crisis management, Journal of Contingencies and Crisis Management, 1(1), 36-50.

Haspeslagh, S (2013) "Listing terrorists": The impact of proscription on third-party efforts to engage armed groups in peace processes - a practitioner's perspective, Critical Studies on Terrorism, 6(1), 189-208.

Hocking, J (2003) Counter-terrorism and the criminalisation of politics: Australia's new security powers of detention, proscription and control, Australian Journal of Politics \& History, 49(3), 355-71.

Hogg, R (2008) Executive proscription of terrorist organizations in Australia: Exploring the shifting border between crime and politics. In: P Mathew, \& Gani, M (eds) Fresh perspectives on the 'war on terror'. Canberra: ANU Press.

Jackson, R. (2005) Writing the war on terrorism: Language, Politics and Counter-terrorism. Manchester: Manchester University Press.

Jarvis, L. (2009) Times of Terror: Discourse, Temporality and the War on Terror. Basingstoke: Palgrave. 
Kertzer, DI (1988) Ritual, politics, and power. New Haven: Yale University Press.

Lovenduski, J (2012) Prime Minister's questions as political ritual, British Politics, 7(4), 314-40.

Lukes, S (1975) Political ritual and social integration, Sociology, 9(2), 289-308.

Moore, SF and Myerhoff, BG (1977) Secular ritual. Assen: Uitgeverij Van Gorcum.

Muller, M (2008) Terrorism, proscription and the right to resist in the age of conflict, Denning Law Journal, 20, 111.

Nadarajah, S and Sriskandarajah, D (2005) Liberation struggle or terrorism? The politics of naming the ltte, Third World Quarterly, 26(1), 87-100.

Neal, AW (2010) Exceptionalism and the politics of counter-terrorism: Liberty, security and the war on terror. Abingdon: Routledge.

Neal, AW (2012) Terrorism, lawmaking, and democratic politics: Legislators as security actors? Terrorism and Political Violence 24(3), 357-374.

Oren, I. and T. Solomon (2015). "WMD, WMD, WMD: Securitisation through ritualised incantation of ambiguous phrases." Review of International Studies 41(02): 313336.

Pantazis, C and Pemberton, S (2009) From the 'old'to the 'new'suspect community examining the impacts of recent UK counter-terrorist legislation, British Journal of Criminology, 49(5), 646-66.

Rai, SM (2010) Analysing ceremony and ritual in Parliament, The Journal of Legislative Studies, 16(3), 284-97.

Rai, SM (2014) Political performance: A framework for analysing democratic politics, Political Studies, 63(5), 1179-1197.

Rappaport, R. A. (1999). Ritual and Religion in the Making of Humanity, Cambridge University Press.

Rhodes, RA (2005) Everyday life in a ministry public administration as anthropology, The American Review of Public Administration, 35(1), 3-25.

Richards, HE (1902) Is outlawry obsolete, Law Quarterly Review, 18, 297.

Ritchie J and Spencer L (2002) Qualitative Data Analysis for Applied Policy Research. In: Humberman A and Miles M (eds.) The Qualitative Researcher's Companion. London: Sage, 305-30.

Sentas, V (2010) The violence of 'terrorist organisation' bans, Criminal Justice Matters, 82(1), 16-17.

Shapiro, JB (2007) Politicization of the designation of foreign terrorist organizations: The effect on the separation of powers, the, Cardozo Public Law, Policy \& Ethics Journal, 6, 547.

Turner, V. (1967). The forest of symbols: Aspects of Ndembu ritual, Cornell University Press.

Turner, V (1977) Process, system, and symbol: A new anthropological synthesis, Daedalus, 106(3), 61-80.

Waylen, G (2010) Researching ritual and the symbolic in parliaments: An institutionalist perspective, The Journal of Legislative Studies, 16(3), 352-65.

Westbrook, R (1999) Vitae necisque potestas, Historia: Zeitschrift für Alte Geschichte, (H. 2), 203-23. 
i The updated list of the UK's proscribed terrorist organisations can be accessed at: https://www.gov.uk/government/publications/proscribed-terror-groups-or-organisations--2

ii We would expect rituals to fall within, across and between the categories suggested here.

iii This follows Rappaport, for whom ritual is 'neither substantive nor functional, but gives primacy to the sensible features common to rituals always and everywhere, the features that may, in fact, lead us to recognize events as rituals in the first place' (1999, p.26)

${ }^{\text {iv }}$ We are grateful to an anonymous reviewer for clarifying our thinking here. As the above suggests, our view is that contributors to these debates know and perform their expected roles, independent of more formalised authority structures therein.

${ }^{v}$ Again, we are grateful to an anonymous reviewer for a particularly incisive comment that shaped this summary. 